\title{
A Thesaurus of Old English
}

\section{The Pilot Study for the Glasgow Historical Thesaurus}

\author{
Jane Roberts \\ Institute of English Studies, University of London, London, \\ Vereinigtes Königreich \\ jane.roberts@kcl.ac.uk
}

\begin{abstract}
The Thesaurus of Old English (TOE), first published in 1995, had its origins in a body of slips derived from standard dictionaries, principally the Clark Hall and Merritt Concise Anglo-Saxon Dictionary and the Bosworth-Toller volumes. These slips were made to supply the Glasgow Historical Thesaurus (HT) project (1965-2009) with a firmer idea of the range and totality of Old English vocabulary than available in the $O E D$. In 1976 the decision was taken to deploy the Old English materials as a pilot thesaurus for the $H T$. With compilation of the slips completed in 1982, researchers were able to begin sorting the slips into groupings based on meaning and to see areas of the $H T$ classification take shape in miniature. The тOE data, absorbed into the larger structure of its parent project, allow us to view English words that disappeared by 1150 alongside those that continued in use.
\end{abstract}

\section{Keywords}

category - classification - meaning - Old English - thesaurus

\section{Introduction}

The story of $A$ Thesaurus of Old English (TOE) begins in 1965, when Michael Samuels announced the Historical Thesaurus $(H T)$ project at a meeting of the Philological Society in London, a project to be undertaken by members of the English Language department at the University of Glasgow (Samuels, 1965: 40). Pointing to the excellence of the Oxford English Dictionary (OED) as an 
account of the meanings English words have held throughout their recorded history, he proposed that the $O E D$ 's contents should be used for the analysis of how concepts are expressed. In effect, he proposed that the $O E D$ should be turned inside out: its contents, once freed from alphabetic arrangement, could be classified according to meaning. A new thesaurus was to be built from the totality of meanings assembled in the $O E D$. It was to be an historical thesaurus, its senses accompanied by the usage dates recorded in the $O E D$, and, complementing the $O E D$, to serve as a research tool for new work on linguistic change. Seven years later, Samuels's influential monograph, Linguistic Evolution, displayed the thinking that lay behind the project, at the same time demonstrating the need for, as he put it in his concluding chapter, a resource that would "bring together under single heads all the words, current or obsolete (and all the obsolete meanings if words still current) that have ever been used to express single and related notions" (Samuels, 1972: 180). When, in 2009, the $H T$ appeared, its introduction described the purpose of the Thesaurus as follows:

... the chronologically ordered lists of meanings ... are intended:

(i) to give a history, with dates of currency, of the words used to express the concept or object stated in the list's heading, including losses, additions, and straightforward replacement; and

(ii) to act as a thesaurus for any period in the past, so that, for example, anyone wanting to know the range of words available to Shakespeare for a particular meaning can consult the relevant section or sections.

$H T$ : I, xiv

\section{$2 \quad$ The Early Years}

There were two main tasks at the outset of the project: the compilation of slips from the $O E D$ and the devising of a new classificatory structure. In default of the yet-to-be invented classification, we used the category numbers of Roget's Thesaurus as an initial means of sorting slips into rough groupings according to meaning (Roget). The Roget numbers were useful in sifting the growing mass of slips into batches which could be sorted into narrower groups according to the meanings each slip held, but it was the meanings on the slips that would form the basis of the new classification. We started out as a group of six, Samuels and five members of his department. Samuels was himself working on the classificatory system; four colleagues set about transposing word meanings taken from the $O E D$ to single slips: Leslie Collier, John Farish and Leslie Blakely, who took on the letters B, T and F, respectively; and James Muir, who was already working with Samuels on aspects of classification, took on 
H. Collier's output of slips was prodigious, more than any other contributor to the project.

My own role was subsidiary, to index Old English vocabulary as a separate archive for research, to make it possible to examine words that had become obsolete by $115 \mathrm{O}$. These were absent from the $O E D$, a dictionary of words in continuous use from 115o. Forty-four years later, in 2009, the Historical Thesaurus (Version 1.0) was published (Figure 1) and, to the surprise of Oxford University Press, went into a third printing within its first few months. A photograph, taken at the 2009 launch party in Glasgow, shows some of the many who collaborated on its making (Figure 2). Today, the two hefty volumes of 2009 gather dust in bookcases, for most people access their data through the online $O E D$. Alternatively, you can go to "The Historical Thesaurus of English" website, where you will find Version 5 of the $H T$, in effect a second edition, together with access to such spin-off projects as "Mapping Metaphor" and "SAMUELs." It amazes me to think both that I left Glasgow University as long ago as 1968 and that I am now the longest serving editor in the $H T$ project.

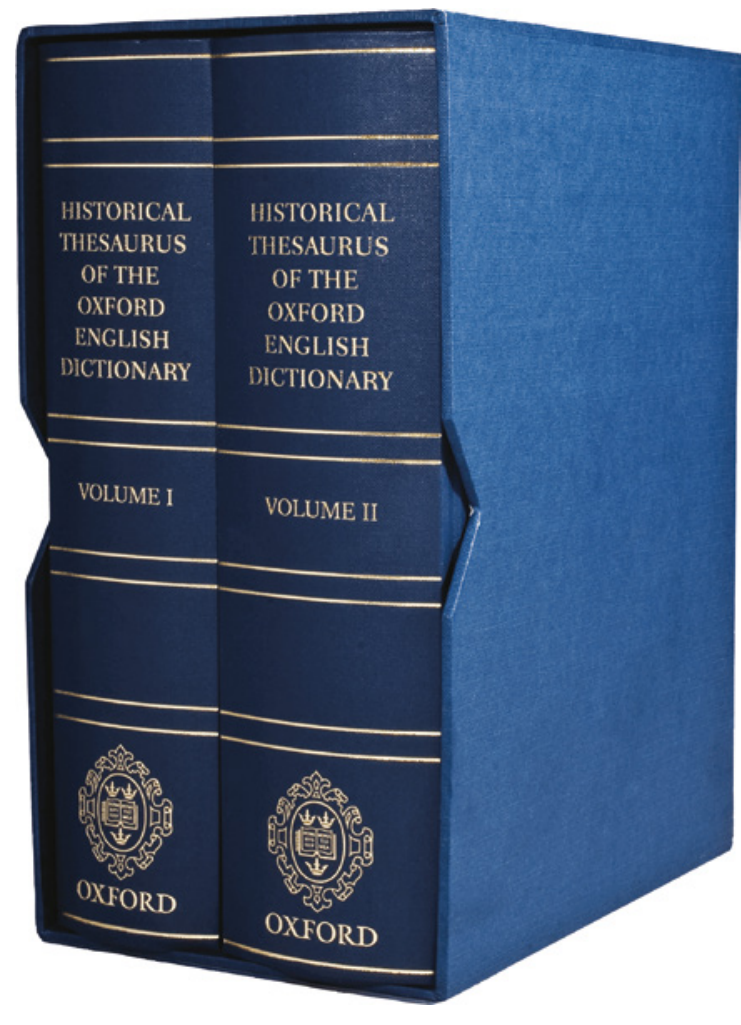

FIGURE 1

Version 1.0 of the Historical Thesaurus, published in 2009

1 For details, see https://ht.ac.uk/story/. 


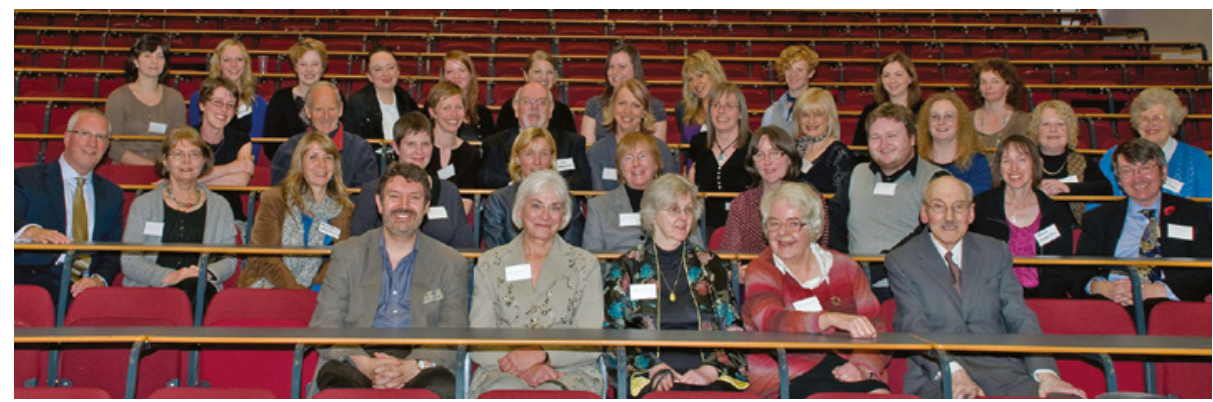

FIGURE 2 All the editors and staff of the Historical Thesaurus who attended the Glasgow Launch Event on 22 October 20og. Back row, left to right: Imogen Marcus, Eilidh Macrae, Jennifer Scammell, Sonia Tinagli-Macrae, Johanna Green, Lisa Harrison, Ellen Bramwell, Kerry Ferguson, Sophie Holmes, Jennifer J Craig, Lesley A Haughton. Third row, left to right: Kate Wild, Jim Muir, Kathryn Allan, Ian B Hamilton, Judith M Paterson, Ann Gow, Mary Watt, Louise Edmonds, Flora Edmonds, Maureen McRobb. Second row, left to right: Thomas J P Chase, Hazel Mills, Margaret Hebenton, Rosie Robertson, Cerwyss O'Hare, Irene E Reay, Rachel D Bell, Marc Alexander, Freda Thornton, Jeremy J Smith. Front row, left to right: John B Corbett, Irené A W Wotherspoon, Jane Roberts, Christian J Kay, Michael Samuels

Late in 1965 , as the entering of word meanings from the $O E D$ on $6^{\prime \prime} \times 4^{\prime \prime}$ slips of white paper got under way, we decided that I had better use yellow slips, to ensure that they could not be mixed up with slips recording $O E D$ information. I was to excerpt the meanings of words recorded in the standard dictionaries of Old English. My principal working tools were the Clark Hall/Merritt Concise Anglo-Saxon Dictionary for headwords and the two Bosworth-Toller volumes for citations (Clark Hall, 1960), to which I added Campbell's Addenda in 1972. The Old English slips were to supply the editors of the $H T$ with a firmer idea of the range and totality of Old English vocabulary than is available in the $O E D$; and I was to work without reference to the $O E D$. Thus, the purpose of the small additional archive of slips was to provide supplementary evidence for the Old English omitted from the $O E D$ : "all words that had become obsolete by $1150^{\circ}$ (OED: I, Xxviii). And it was to draw on alternative sources, to ensure that the decisions taken by the editors of the $O E D$ did not influence me.

Quite early on I set myself a minimum daily target of twenty-five slips, approximately an hour's work, and I entered ticks in my diary to record each stint completed. The ticks could sometimes fall behind in term-time, to be made up during vacations. I entered a tally of slips per lexical entry into my copy of Clark Hall and, for my own use, I made copies on white slips which I kept alphabetically arranged-it was essential to have this set of slips for crosschecking while I worked through all the letters of the alphabet, because 
the source dictionaries were inconsistently lemmatized, with the citation evidence for word meanings widely scattered. Sometimes, there were twelve or more entries to check in Bosworth-Toller for a single word, contradicting, correcting and supplementing one another. The Grein-Köhler dictionary was an invaluable help for words in the poetic corpus, but very often it was necessary to go back to the texts themselves in whatever editions I could lay my hands on. The yellow slips went into the $H T$ filing drawers in the English Language Department at Glasgow.

Words beginning in $\mathrm{C}$ were the first to be indexed, for a variety of reasons: it is not the first letter of the alphabet - best left well alone until working patterns were established; $\mathrm{C}$ is relatively short; there were no prefixes to bother with other than ge-; there weren't all that many spelling variants apart from those thrown up by initial palatalization. $\mathbf{D}$ was next. It was all low tech, just paper and pencil. On the slip illustrated (Figure 3), you see at the centre the word delfin, a word with a single sense that is written across the top, a word recorded as Old English in Bosworth-Toller. For reasons that will become apparent, this is a yellow slip that never did go to Glasgow. In the top left-hand corner, I entered Roget numbers as an initial rough and ready sorting device, for the new classification still lay far ahead. Merritt ruled that delfin was not recorded in Old English, a decision confirmed first in Campbell's Addenda (1972) and later by the word's absence from the first fascicle of Toronto's Dictionary of

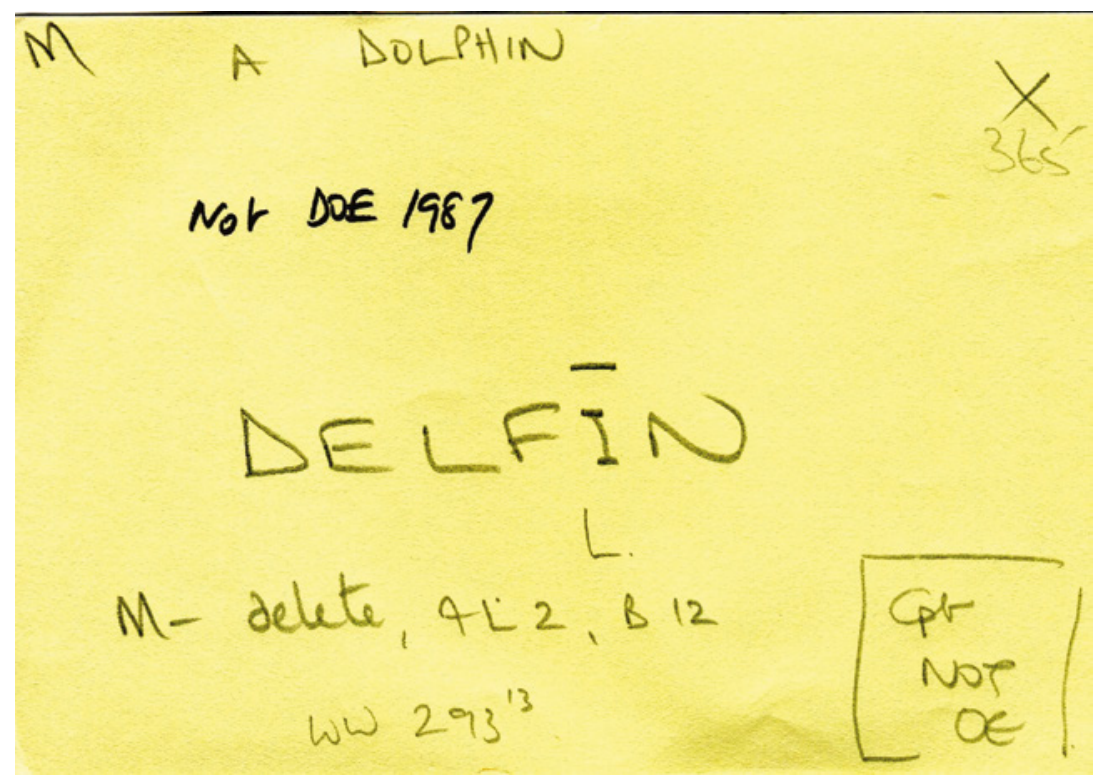

FIGURE 3 Yellow slip for the word delfin 
Old English, D (1986). In contrast, my white slips, on which this information was replicated, had the word form across the top of the slip, with the meaning below: a precautionary arrangement to enable recognition (and return to me) should any white Old English slip stray into $H T$ boxes. That, of course, was no longer a problem once I moved jobs, first to Dublin and then to London. From the start the white slips were filed alphabetically. As for delfin, the retention of its yellow slip in my own files meant that it did not get into the $H T$ files.

All the time, work continued on devising the classification, often informed by working with bundles of slips, where meanings led the sorting-classification is from the bottom up. In the earliest stages of developing the $H T$ classification, initial studies were undertaken by Muir and by Irené Wotherspoon, the project's first postgraduate student (Wotherspoon, 1970). Wotherspoon examined the descriptive problems presented by two contrasting lexical fields, one containing concrete vocabulary (parts of the body), one abstract (mental pain). The abstract vocabulary was relatively easy to extract from the growing $H T$ files, but it was harder to track down the words for parts of the body, since these slips were dispersed widely about Roget's 99o categories (see Roberts, 1978: 6o-61). As we had known would be the case, the Roget numbers proved unsatisfactory, and especially so for concretes, but they provided slip compilers with a common grid. Over time, we came to realize many of the category numbers were so wide in possible content that they were best avoided; and although modifications to Roget were discountenanced, we did take to placing all parts of the body under a new number, 1001. Christian Kay, then working in publishing, joined the project part-time in 1969, to work directly on the classification with Samuels towards a part-time PhD. In 1975 their publication of a paper on the usefulness of "Componential analysis in semantics" showed that significant progress had been made with the new classification (Kay and Samuels, 1975). Yet, a year later Samuels was so worried by the lack of progress in extracting meanings from the many volumes of the $O E D$ that he had begun to wonder if the project should continue.

Come the summer of 1976, as it happened I was up in Glasgow for an examiners' meeting. During that visit, Michael Samuels summoned Christian Kay, Irené Wotherspoon and me to an informal meeting, at which he flabbergasted the three of us by announcing either that we were, with him, the future of the thesaurus or that the whole enterprise faced collapse. As a result of that quick meeting over coffee, it was Christian Kay who, many years later, got the Historical Thesaurus completed. A few days after that informal meeting Kay wrote to me: "Before last week, I don't think I had realised how serious the financial position of the thesaurus was ..." Kay fixed her eye quickly on the dire financial straits of the project and by December she had drawn up an impressive work 
plan which was instrumental in gaining the project's first major grant, from the British Academy. It was fortunate that Kay took up a lectureship in the English language department in 1979, for, when in 1981 a new source of funding opened up in the form of government-sponsored programmes for people to learn new skills, she was quick to establish training programmes in editing and data entry in return for a stint of work on the project. At the beginning there were three trainees, with the scheme peaking at nineteen. This development necessitated changes in the way the project was managed: a new stage of pre-classification was introduced, where trainees prepared sections of classification for future work by more experienced editors. It also saw the beginning of bulk inputting of data, coinciding with one of the major developments of the 1980s: the increasing use in Arts research of computers for storage and manipulation of data. Not only was completion now feasible, but the first steps towards publication were under way.

One unexpected consequence of the quick meeting over coffee in 1976 was the decision to put together a self-standing thesaurus of Old English. In London, twenty-four green fire-proof boxes contained my alphabetically ordered duplicate slips, a small separate body of materials that could be used independently of the main thesaurus. By then, I had sent slips for all but five letters of the alphabet to Glasgow, and it was agreed that once I had finished making slips for all the letters, work towards a pilot thesaurus of Old English could begin. The pilot would have two primary functions. It was to serve as a test bed for the new classification and as a proof, in small, that we could actually finish something. I foresaw that this would entail breaking up what had become, word by word, a most useful integration of the contents of the Old English dictionaries. Once the slips moved into groupings based on meaning, their relationship to particular dictionary headwords would be lost, and I needed an alphabetic record of the slips-in Glasgow, the $H T$ compilers ticked $O E D$ entries as each slip was made, but the varied materials from which I extracted word senses had made such a simple procedure impossible. Luckily, as I neared the end of compiling slips, George Kane, my head of department, let me know: "The scientists are looking for an Arts project to play with, and that sounds the sort of thing they need." He packed me off to see the professor of chemistry, who passed me on to the computing department, where I was greeted with open arms and Christine Brown designed the necessary program. I wanted a record of alphabetically arranged materials ahead of sorting them into semantic groupings? Certainly. 
At first there were two Fortran cards per slip: one for word form + meaning and one for word form + Roget number(s), but I soon decided that a single card (Figure 4) was enough and less risky — I had become worried that the two might not always be linked and in any case I could not see that both were absolutely necessary. Also, the retreat to a single card decreased the amount of time spent by the willing people who were doing the inputting and the amount of time I spent checking their work.

I finished compiling the Old English slips in 1982. The last letter slipped was F, which was inordinately long because it is one of the few letters for which the Harley Glossary survives. Soon afterwards, my computing colleagues furnished me with nine microfiches, giving both alphabetical and numerical checklists, the latter a skeleton Old English thesaurus according to broad Roget groupings. This was the $H T$ project's first overview of thesaurus materials (Roberts and Brown, 1982)..$^{2}$ Now it was time to start moving my white slips out of alphabetic order. First, I did a broad sort of some 46000 slips into Roget numbers, except that slips for parts of the body went into the rogue number 1001. The slips gathered together under each holding number could then be sorted into batches according to what was the important information on each slip, the particular word sense. Endlessly it seemed I sorted and re-sorted, and wrote out lists which I posted up to Glasgow.

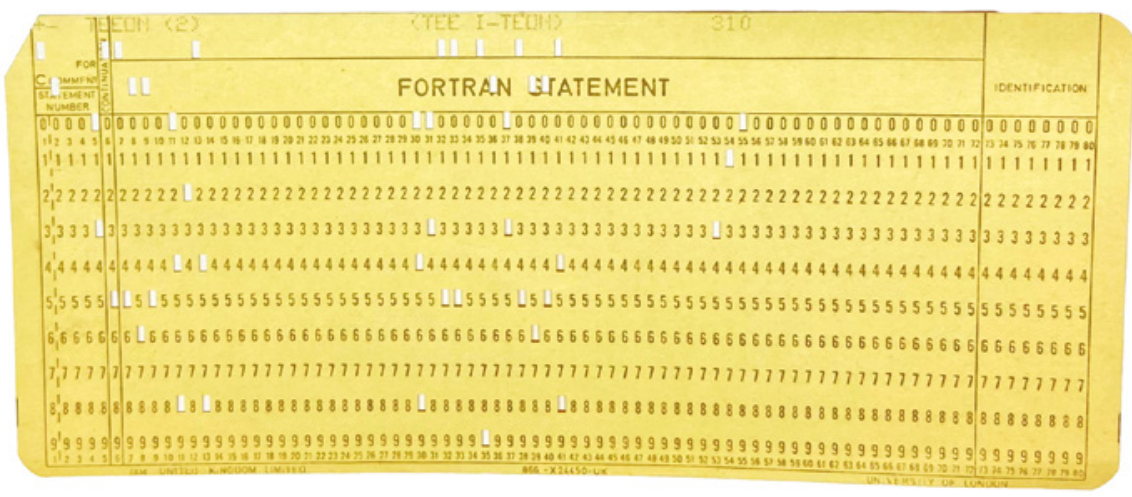

FIGURE 4 A Fortran punch card for one meaning of (ge)tēon, sorted initially to Roget 310. See now TOE online at "05.12.05.12.02 To raise, lift up, elevate," where têon üp is placed

2 For discussion of this stage see Roberts (1982). 
By now Christian and I had the provisional classification she and Michael had devised for the $H T$, and we cut back its more elaborated structure to the eighteen categories of the TOE, but holding to what is essentially the same sequence (see Table 1$).^{3}$

The headings across the top row are the headings of the main thesaurus. The three sections we kept (for the $H T$ the three blocks were held in separate files because at that time computers did not allow for such large amounts of data in a single file), but sizeable blocks of slips moved about within the overall structure. The major divisions of the TOE are listed in volume I, pp. v-viii, an essential key for understanding the ordering of contents; it should be consulted for guidance towards finding words for a concept.

TABLE 1 The categories of the TOE

\begin{tabular}{lll}
\hline WORLD [HT 1-8] & MIND [HT 9-16] & SOCIETY [HT 17-26] \\
\hline o1 The Physical World & o6 Mental Faculties & 12 Social Interaction \\
o2 Life and Death & o7 Opinion & 13 Peace and War \\
o3 Matter and Measurement & o8 Emotion & 14 Law and Order \\
o4 Material Needs & o9 Language and & 15 Property \\
05 Existence & Communication & 16 Religion \\
& 10 Possession & 17 Work \\
& 11 Action and Utility & 18 Leisure \\
\hline
\end{tabular}

The most striking modifications of the $H T$ classification are summarized roughly in Table 2, which gives a flavour of some of the major changes made (see Table 2).

TABLE 2 Some $H T$ missing categories

\begin{tabular}{lll}
\hline WORLD $5<7$ & MIND $6<8$ & SOCIETY $7<\mathbf{1 1}$ \\
\hline O3 Sensation and Perception & 11 Aesthetics & $\begin{array}{l}19 \text { Government and Politics } \\
\text { 07 The Supernatural }\end{array}$ \\
& 12 Volition & $\begin{array}{l}21 \text { Education } \\
23 \text { Communication, the Media } \\
\end{array}$ \\
& 24 Travel and Transport
\end{tabular}

3 These differences are discussed in Roberts (1998a) [invited update of a paper given at a seminar held in Utrecht in 1993]. 
In all, eight $H T$ categories disappeared. The reduction is especially noteworthy in Section III, where there are seven TOE categories by comparison with the eleven of the $H T$. In the TOE "18 Leisure" is the smallest category; in the $H T$ it is massive. Such $H T$ categories as "11 Aesthetics", "19 Government and Politics", and "23 Communication, and the Media" have few Old English words, hardly enough to merit a separate category. As we worked with the Old English word meanings (at my end slips were positioned in new semantic groupings, and the hand-written lists, of which I kept copies, were posted to Glasgow), it felt wrong, for example, to have a separate category for "The Supernatural" separate from organized religion, and we opted therefore to integrate the two under "16 Religion", where God, devils and magical practices consort with what is in the $H T$ "22 Institutional Religion". A large category that moved in the opposite direction was $H T$ "24 Travel and Transport" (Roberts, 1998b: 12-13). The fairly basic Old English vocabulary seemed to fit best with the more general lexis for movement in o5 Existence. Anglo-Saxon England did not have canals, railways or aeroplanes. Most people walked. A few had horses. Carts and carriages must have been rudimentary, with boats a more reliable means of getting across country and sea travel filled with danger. There is little differentiation even among types of sails. The few groups of Old English words relating to "21 Education" we parked in TOE "og Language and Communication".

Thus, the editing of the TOE allowed us to explore the use of the $H T$ classification, to build up blocks of material and to experiment with how they should be most efficiently positioned within the whole. It was exciting to rearrange, gradually, the 46 , ooo or so slips, to see areas of the $H T$ classification take shape, in small. At the Glasgow end, Christian worked from the lists I had drawn up, supervising the initial keying in of the materials from the mid-198os (Apricot floppy discs began to be posted south in the late 8os). Through all these years Christian and I found the Skeleton Thesaurus microfiches very useful, and it occurs to me that even now the alphabetic list could be used to help check for words that senses belong to, something that some users have asked for. Volume II is not a word index but an index of where senses for forms of similar shape are to be found in the thesaurus itself (volume I). For the most part, the locations listed under a headword in volume II do relate to a single word, as, for example the uncommon noun torn, with addresses in GRIEF, ANGER and SEVERITY/HARSHNESS. But some headings can draw together words from separate roots, for example sìde, where a native word meaning 'side, hill, etc.'

4 For some discussion of $H T$ "21 Education" see Roberts (2000); see also Sylvester and Roberts

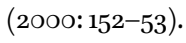


and the loanword with the meaning 'silk' converge. The decision taken early to supply words with length marks does at least keep gōd (>good) and god (>god) apart.

For six months in 1985-86 I held a Leverhulme grant to release me from most of my teaching, making it possible to concentrate attention on the TOE. By then, about $90 \%$ of the slips had been sorted into groups determined according to shared components of meaning, and in celebration we sent off a progress report to the Medieval English Studies Newsletter (Roberts and Kay, 1986: 1-3). But, to Christian's dismay, I threw a spanner in the works by wanting to add a minor layer of information. 1986 was the year in which the first letter of the Toronto $D O E$ was published, but ever since the publication of the Toronto Microfiche Concordance to Old English (1980), I'd been mulling over just how feasible the inclusion of usage flags might be. ${ }^{5}$ Unexpectedly, a most generous gift arrived in 1988 from the editors of the Toronto dictionary, a CD-ROM containing the Toronto Corpus of Old English, sent by way of thank you for the Skeleton Thesaurus fiches, which they were finding useful. This gift meant it was now a practical proposition to conduct spot checks on uncommon words and to reconsider meanings where the definitions found in the standard dictionaries were opaque. We settled on four superscript flags to supply some simple distributional information. It was relatively easy to identify words that occur only in poetry, and these could be flagged $\mathbf{p}$. Words that occur once only should be flagged $\mathbf{o}$, with $\mathbf{g}$ marking out words that occur only in glossing materials. There were dubious words too among the slips, words that had found their way into the dictionaries, maybe from out-of-date editions or reconstructed from place-name records. Rather than discard them, they needed to be retained with a clear a warning signal; so $\mathbf{q}$ for query was chosen to draw attention to questionable forms. The flags are not carried forward into the HT because there the word senses either map on to $O E D$-derived forms or remain stranded, but they are retained in the web version of the TOE. Another stroke of luck occurred in 1988: King's College appointed Harold Short to a new post specifically in Computing Services for Humanities and Information Management. Short was responsible not only for much of the TOE's technical database work, but he was also to create the processes required to get from database to camera-ready copy. And 1988 was the year in which the first of the TOE reports in the Old English Newsletter appeared.

5 Discussed at the Toronto meeting of ISAS (1987); see Roberts 1988, 21-23. 
1989 was when editing proper got under way. That autumn Lynne Grundy joined me in London as part-time research assistant funded by the King's College research fund. ${ }^{6}$ From computing, Harold Short, advised us. First, all the current Apricot files held on floppy discs were loaded into a new system, a relational database, and we set about entering data and updating files, initially working with a personal computer but in 1992 the files were transferred to the college mainframe computer. Harold Short eventually devised and ran the programme that generated photo-ready copy for publication in 1995 and 2000 and from which in 2005 TOE Online was developed and its 2017 iteration. The technical details are all to be found in the "Introduction" to the $\operatorname{TOE}(1995,2000)$. We were able to do a great deal of cleaning up the materials taken from the old dictionaries because of the CD-ROM version of the Toronto Dictionary of Old English Corpus in addition to the letters of the alphabet by then edited by the $D O E$ team. ${ }^{7}$ We checked not just the four flags but on the very existence of the word senses extracted from the source dictionaries. As we worked through the files, the $\mathbf{q}$ flag became extraordinarily useful because, often, we were able to match up forms and dispense with it. It took from November 1989 to April 1993 to get all the files strung together, with a first round of revisions that April. Across May to September 1993 we read through the preliminary printouts, as did Michael Samuels and Janet Bately. After the second round of revisions there were two further rounds of proof: stage 1 from July to October 1994; and stage 2 in August 1995; both stages were read by Grundy, Kay, Roberts and Samuels, with Short checking for indexing problems. As for the metalanguage (explanations of meaning, in bold), even at the final proof-reading stage we were still removing archaic words inherited from Bosworth-Toller, for example leman, liever, and withershins, an exercise enjoyed particularly by Samuels. ${ }^{8}$

The eighteen categories of the TOE cater for all the word meanings recorded for Old English. Roughly, categories 1-5 more or less cover the world as it is out there (it is a man-centred folk taxonymy): it begins with what we see around

6 Lynne Grundy held research appointments in the Department of English at King's College (1989-1993), working with Christian Kay and me on the TOE alongside teaching Old English in Queen Mary College and Royal Holloway College. From 1993 to her early death in 1997, she worked in the Centre for Computing in the Humanities at King's, where in 1995 she was appointed Lecturer in Humanities Computing, the first post of this kind in the United Kingdom.

7 Fasc D (1986), C (1988), B (1991), Æ (1992, Beon (1992) and A (1994) of the DOE had been published.

8 See further Kay and Roberts (2004: $5^{8-63)}$. 
us, land, sky, sea, etc., moves on to the living beings, their characteristics, their physical needs and the material world around them, and ends with ways of interpreting and quantifying the world, through analysis of time, space, measurement. Categories 6-11 contain word senses used for mental processes, e.g. for thought, emotion, will, together with language and possession. Finally, categories 12-18 represent the social world. Here is the vocabulary of the elaborated structures created by man operating within the physical world: communities, war, law, property, religion, work and relaxation.

Within this framework there is provision for seven main category levels and two sub-categories in a taxonomy that begins with the most general ways of expressing a concept and moves hierarchically downwards to the most specific. All nine potential levels are sometimes occupied in expressing the objects of the material world, where a good deal of detail can be specified, but are less often needed in the broader divisions of abstract categories. To look at these levels in use we shall focus in on the opening category:

\author{
o1 Earth, world \\ 01.02 Firmament \\ 01.03 Air surrounding earth, atmosphere \\ 01.03.01 Weather, condition of atmosphere \\ 01.02.01.06 Cloud \\ 01.03.01.06.04 Snow: snaw(a), wintergewæde ${ }^{\text {op }}$ \\ -Snow-storm: snaw, snawgeblando \\ -Snow-flake: flæp \\ -Snowy: snawigo, snawlic \\ -To snow: sniwan
}

..To cover with snow: besniwanog

[Superscript flags: $\mathbf{o}=$ recorded once; $\mathbf{p}=$ found only in poetry; $\mathbf{g}=$ found only in glosses and lists of vocabulary; $\mathbf{q}=$ a doubtful form.]

To the left, in bold, headings indicate meaning within the overall structure; the wording of the definition reflects the part of speech (thus, snowy is an adjectival form, and $T o$ opens verb explanations). If the word we are interested in is the verb besnew (a word found also in later English, but recorded once only in Old English), we place it by reading back through the explanatory information. To besnew, with two dots, is a type of snowing, i.e. of the verb to snow, with one dot, which is subordinated to the noun-headed sub-category snow. 'Snow-storm', 'Snow-flake', 'Snowy' and 'To snow', all with single dots, are coordinate. Above this final group within the first of the eighteen categories is 
displayed the numerical hierarchy that indicates preceding definitions relevant to this group of sNow words. Moving upwards through the relevant steps, we see that 'Snow' depends upon 'Cloud', that 'Cloud' relates to 'Weather, condition of atmosphere', which is in turn part of the 'Air surrounding earth, atmosphere'. The next upwards step is to 'Firmament' and at the very top, for this is a man-centred classification, 'Earth, world'.

It must be understood that the TOE presents the word senses available to Anglo-Saxons for expressing concepts. Headings are not definitions but indicate a meaning range. Above, where only two forms follow the heading "01.03.01.06.04 Snow", the unflagged $\operatorname{snaw}(a)$, is likely to have been the usual word for snow then as now; wintergewcede is flagged as very infrequent and restricted to poetic texts. Contrast the opening two noun entries for "o8.01.03.05.02 Anger", where the reader is confronted by a largish number of loosely synonymous alternatives without guidance as to which might be prototypical:

08.01.03.05.02 n. Anger: ǣbylg, ǣbylgag, ǣbylgb(u), gebelg, grama, iernes, ierscipe ${ }^{\text {og, }}$, wrǣppu

o1 n. Anger, wrath, fury: ǣbylgnes, gramfǣrneso, hātheort(e), hātheortnes, hāthige ${ }^{o p}$, ierre, mihtmōo ${ }^{\mathbf{o p}}$, rēpscipe, gerīoso, torn, wēamēt(tō), wēamōdnes, wielm

-A rage of darts: gārtornop

-Unrighteous anger, rage: torn

-Woman's fury: wīfgemǣdla

-Readiness to anger, irascibility: irsung

-Gnashing of teeth in anger: gyrst ${ }^{q}$

With so many forms on offer, it is well to heed Christian Kay's warning that "... not all members of a category are equally central, and that consequently meanings overlap and the boundaries of categories are blurred." ${ }^{\prime 2}$ The flags indicate that some forms are hardly central. Of the other forms on offer, the likeliest central terms are ierre ( $O E D$, s.v. †irre $\mid$ erre, n.), in use into the early fourteenth century (see $M E D$ ) and wrēppu (OED, s.v. wrath, n.). Contrast the following five rows, each with only a single Old English form. Consequently, the metalanguage is more precise, and these entries resemble dictionary definitions. There is one poetic hapax legomenon, MSol 141 gärtorn. ${ }^{10}$ Next torn appears

9 Kay (2000: 58-61), where this concept is discussed, at 58. Romano (1999:47) includes both ierre and wrap among eleven nouns listed as examples "of the most prototypical members of the category."

Short titles for Old English texts are as in $D O E$ publications. 
again, and it is to be found also among words expressing the concept GRIEF. It is relevant to point out that torn, whether noun, adjective, the adverb torne or in compounds, does not survive into Middle English. Moreover, it occurs only in poetic texts, apart from one DOEC citation, Or 112.33.20 "hie swipe tornwyrdon" ("torn wyrdon" in both manuscripts; in the earlier manuscript torn is the last word on a page). The compound wifgemēdla occurs only in Bald's Leechbook, in a heading Lch II (3 Head) 57 "Wip wif gemædlan" and repeated immediately in the recipe'sopening, Lch II (3) 57.1.1 "Wip wif gemædlan geberge on neaht nestig rædices moran." [For madness in women, eat at night, fasting, heads of radish]. Last, gyrst, flagged as questionable, occurs in glosses but is perhaps elliptical for gristbitung 'gnashing of teeth', hence 'anger'; but it is cited under †rist, $\mathrm{n}^{1}{ }^{1}$ in the $O E D$, together with a second citation "Py heued hatz nauper greme ne gryste" [Your head has neither anger nor spite] (Pearl, l. 465) (Kay, 1994: 28).

In this section, I've tried to give some idea of the structure and contents of the TOE and of its early history. The first samples pleased our publisher, Aberdeen University Press, and all seemed to be going smoothly until famously, its owner, Robert Maxwell, fell off his yacht in 1991; AUP went into liquidation in 1992. Yet again, King's College computer colleagues came to the rescue. Ever calm and supportive, Harold Short pointed out that in computing they had done all the work on the database from which the thesaurus was to be generated, so why not publish it ourselves? In 1993 Christian, Lynne and I went to the ISAS ${ }^{11}$ conference at Stony Brook, where we delivered complementary papers announcing that the TOE would soon appear, papers published in the Old English Newsletter in 1994. The first paper, by Kay, opened: "The Glasgow Historical Thesaurus $(H T)$ is the parent of $A$ Thesaurus of Old English, but is in the somewhat unusual position for a parent of seeing its child leave the nest before it itself is fully fledged" (Kay, 1994: 28-29). Huge advance sales resulted in so large a bubble-wrapping operation that David Hook, the KCLMS series editor, swore he couldn't face a second printing. In 2000 a second impression incorporating minor revisions was published by Rodopi, who generously allowed us to put the TOE online in 2005; print copies (2002 version) are still available from Brill. The online $T O E$ received a handsome makeover in 2015 and occasional updates continue to be entered into its database from time to time. A note of some academic reviews follows the reference list at the end of this article. ${ }^{12}$

\footnotetext{
11 International Society of Anglo-Saxonists, now the International Society for the Study of Early Medieval England (ISSEME).

12 For a fuller follow-up article by one reviewer, see Watanabe (2002).
} 
Thinking back, there were other flags I toyed with. Would it be possible to supply some etymological information, say flag with $\mathbf{c}$ words that have cognates in other Germanic languages? If Latin loan words were flagged by superscript l, then cl could flag Latin words likely to have been absorbed into common Germanic before the Anglo-Saxons got to England; thus wall, a word much in the news at present, would have not only the flag $\mathbf{c}$ but $\mathbf{l}$ as well. Or what about $\mathbf{n}$ for Old Norse or $\mathbf{f}$ for the few French words that crept into late Old English? As I reflected on the difficulties of identifying Scandinavian loans (think till or call, and the need to add explanations of decisions taken), common sense kicked in and I turned my back on such ideas. Etymological and distributional information do not mix well. The four agreed flags would provide a roughand-ready distributional guide, allowing a reader to see just which word forms are found only in verse texts and to glimpse, by a process of elimination, the everyday word forms recorded from Anglo-Saxon England. But Evoke (Stolk, 2018) is an excellent medium for new research, for supplying etymologies, to set up as full a record as possible of loan words, in order to see how they are distributed across the categories and subcategories of the thesaurus classification. Further work could lead to the examination of loan translation and word formation, dialect vocabulary, etc.; and Evoke provides a welcome platform for such undertakings.

Other desiderata spring to mind. For example, new work is needed on the multiword units of Old English. Linguists have shown a lot of interest in phrasal verbs, but less in how established collocations supply particular concepts. Both were ill-served in the older dictionaries. To-day in English we are more likely to use the phrase 'make peace' rather than the verb 'pacify', and earlier English had its phrases too, as is clear from some examples of ways in which this concept was expressed up to $155^{\circ}$ (see Roberts, 2002):

Make peace: fon to fripe, fon to sibbe, frip (ge)niman, fripian, macian frip, grith<gripian $\mathrm{OE}-c 1205$, make peace $c 1154-$, make grith $a 1175$, make sib $a 1175$, pease $1297-1611$, enforme the pes $c 133$ O

We see the importance of fon, macian and niman as prop words in phrases well-established in Old and Middle English. Phrases do not have flags in the $T O E$, and they are underrepresented in both the TOE and the $H T$.

There are many ways in which readers of a thesaurus can play with its data. Let me finish with two visualizations that draw on the Glasgow $H T$. The first shows, across time, the interjections used for expressing sorrow (data supplied by Marc Alexander from the second edition of the Glasgow $H T$ ): 
02.04.11.03.02.03 (int.) Cry of grief

O1 specific cry of grief eala OE $\cdot$ eow $\mathrm{OE} \cdot \mathrm{euwa} \mathrm{OE} \cdot$ higla $\mathrm{OE} \cdot$ wa la $\mathrm{OE} \cdot$ wel la wel $\mathrm{OE} \cdot$ wella $<$ wel la $\mathrm{OE}-\mathrm{C12O} \cdot$ weila $<$ wegla $\mathrm{OE}-c 123 \mathrm{O}^{\cdot}$ walawa $<$ wa la wa $\mathrm{OE}-c 13 \mathrm{Oo} \cdot$ weilaway<wei la wei $\mathrm{OE}-c 1440 \cdot$ woe $<$ wa $\mathrm{OE}-($ now arch.) . wumme $c 1175^{-a 1225} \cdot$ wi $a_{1200-a 1300} \cdot$ wellaway $c 1200-1657 ; 1818-($ arch.) - wale $c 1205(2) \cdot$ woe is me $c 1205^{-}$(now arch. \& dial. ) ' wolowo $a 1225^{-c 1400}$ - wailaway $a 1250-1513 \cdot$ alas $c 1225^{-} \cdot$ full/so wellaway $a_{1300-1513} \cdot$ walaway a130o-1724 ' a $c 1300-15^{23} \cdot$ out $c 1386-1924 \cdot$ wellawo $a 1400-c 1500 \cdot$ weleaway a140o-1616 • wellesay c140o-c1499 ' alas/worth/worried be/God help/woe the while c1402-1596; 1825 (chiefly arch. \& poet.) ' ah c1440- · wannowe $c 145^{\circ} \cdot$ ohone $c 148 \mathrm{o}-($ Scots \& Irish) $\cdot$ helas $1484-1753 \cdot$ halas c1500-1610 • och a1521- (Scots \& Irish) · ah me a1546- · wough $a_{1553} \cdot$ woe worth 1553-1598 ' welladay c1570-(now arch.) ' how 1575/6; c1750 (Scots) • ogh $1582 \cdot$ ay me $1591-\cdot$ well-anear $1600-1677 ; 1787-($ dial. $) \cdot$ las $1604-1844$ $\cdot$ good lack 1638-1807' oime(e) 166o; $1820 \cdot$ pillaloo $1663^{-} \cdot$ well-anearing 1683-1829 • lack-a-day $1695^{-1849} \cdot$ waly a1724- (Scots \& northern dial.) lackadaisy $1748-1847 \cdot$ waesucks $a_{1774-}($ Scots $) \cdot$ well-a-wins $a_{1773-1898}$ $($ Scots $) \cdot$ wella welladay $1805^{-1820} \cdot$ wirra $1825^{-}($Irish $) \cdot$ wirrasthru $1827-$ (Irish) · mavrone 1827-1939 (Irish) · ullagone 1828 (Irish) • ochone c1850-· ototoi $1877-($ Greek $) \cdot$ woe worth me $1887-\cdot$ wurra $1898-($ Irish $)$

It's fairly indigestible, requiring slow reading. In Table 3 below the vanished and infrequent forms are stripped out, to give a more readable diagram (see Table 3).

Reading downwards gives dates for when the forms shown are first recorded. Across the top are ad hoc labels. It seems that, when sad, the interjections usual in $\mathrm{RP}$ are alas and ah. To my ear, these are a tad formal; my default interjection is och. People are touchy about the interjections they use. I once asked one of my PhD students why, like me, she often said och. She bristled with fury and replied: "I must have got it from my father." I had no idea that her father was, like me, from the north of Ireland. She was obviously upset at realizing she had one of his speech-habits.

Like the Glasgow $H T$, for which it was a pilot study, the lists of meanings in the TOE are intended to give a story "of the words used to express the concept or object stated in the list's heading" (HT: I, xiv). Unlike the $H T$, the $T O E$ centres on a single period. There are no dates of currency (well, have you ever believed in the dates for $\mathrm{OE}$ texts to be found in $O E D_{2}$ ?). There is therefore no record of losses or additions, and little possibility of estimating replacement. But its data did, when absorbed into the larger structure of its parent project, the Glasgow Historical Thesaurus, for the first time allow us to glimpse those words that disappeared by 1150 alongside those that continued in use. 
TABLE 3 The more common exclamations of grief

\begin{tabular}{|c|c|c|c|c|}
\hline Date Central & Formal & Now archaic & $\begin{array}{l}\text { Scots } \\
\text { (\& nth.) }\end{array}$ & $\begin{array}{l}\text { Sc. \& Ir. } \\
\text { Engl. }\end{array}$ \\
\hline
\end{tabular}

$\begin{array}{lll}\text { OE } & & \text { woe- } \\ \text { ME } & \text { alas } c 125^{-} & \text {wellaway } \\ & \text { ahc1440- } & c 1200^{-} \\ & & \text {woe is me } \\ & 1205^{-}\end{array}$

S. XV

$\begin{array}{cll} & & \begin{array}{l}\text { ohone } \\ c 1480-\end{array} \\ \text { ay me } 1591- & \text { welladay } & \text { och } a 1521- \\ \text { ah me } a 1546- & c 1570- & \\ & \text { well-anear } \\ & 1600- & \end{array}$

S. Xviii

waly $a 1724-$

pillaloo 1663-

waesucks

a1774-

well-a-wins

a1774-

s. xix

ototoi $1877^{-}$

woe worth me

wirra $1825^{-}$

1887-

ochone

c1850-

wirrasthru

1827-

mavrone

1827-1939

1892-

wurra 1898

\section{References}

Bosworth-Toller = An Anglo-Saxon Dictionary, Based on the Manuscript Collections of the Late Joseph Bosworth, Edited and Enlarged by T. Northcote Toller (London: Oxford University Press, 1898-1921). Campbell, A. Enlarged Addenda and Corrigenda (Oxford: Oxford University Press, 1971).

Clark Hall, J. R., with supplement by H. D. Merritt, eds. A Concise Anglo-Saxon Dictionary, 4th edn (Cambridge: Cambridge University Press, 1960). 
$D O E=$ Cameron, A. F., A. C. Amos, A. diPaolo Healey, S. Butler, J. Holland, D. McDougall, and I. McDougall, eds. Dictionary of Old English. (Toronto: Pontifical Institute of Mediaeval Studies, 1986-).

DOEC = Healey, A. diPaolo, ed. Dictionary of Old English Web Corpus. (Ann Arbor: University of Michigan Press, 2009).

Evoke = Stolk, S. Evoke (Web application, 2018), http://evoke.ullet.net/.

Grein, C. W. M., and J. J. Köhler, eds., Sprachschatz der Angelsächsischen Dichter (Heidelberg: C. Winter, 1912).

Grundy, L. "The Structure of a Thesaurus of Old English." Old English Newsletter 27 (3) (1994), 25-27.

$H T=$ Kay, C., J. Roberts, M. Samuels, and I. Wotherspoon, eds. Historical Thesaurus of the Oxford English Dictionary (Oxford: Oxford University Press, 2009).

Kay, C., and J. Roberts. "Definitions for a New Age." Poetica 62 (2004), 53-68.

Kay, C., and M. L. Samuels. "Componential Analysis in Semantics: Its Validity and Applications." Transactions of the Philological Society 74 (1) (1975), 49-81.

Kay, C. "From HT to toE (or Vice Versa)." Old English Newsletter 27 (3) (1994), 28-29.

Kay, C. "Historical Semantics and Historical Lexicography: Will the Twain Ever Meet?" In Lexicology, Semantics and Lexicography in English Historical Linguistics: Selected Papers from the Fourth G. L. Brook Symposium, eds. J. Coleman and C. Kay (Amsterdam: John Benjamins, 200o), 53-68.

$O E D=$ Murray, J. A. H., H. Bradley, Sir W. A. Craigie, and C. T. Onions, eds. The Oxford English Dictionary (Oxford: OuP, 1884-1933). Burchfield, R. W., ed. Supplement (Oxford: OuP, 1972-86). Simpson, J. A., and E. S. C. Weiner, eds. The Oxford English Dictionary. 2nd edn. (1989). Simpson, J. A., Edmund S. C. Weiner, and M. Proffitt, eds. Additions Series (Oxford: Oup, 1993-97). Simpson, J. A., ed. The Oxford English Dictionary. 3rd edn (March 2000-). oED Online (Oxford: Oxford University Press, March 2000), http://www.oed.com/.

Roberts, J., and C. Brown. Skeleton Old English Thesaurus. Research tool on 9 microfiches. Prepared with Christine Brown at the King's College London Computing Centre (1982).

Roberts, J., and C. Kay. "An Old English Thesaurus: A Progress Report." Mediaeval English Studies Newsletter 15 (1986), 1-3.

Roberts, J. “A Thesaurus of Old English: One Snapshot of a Vanished World." NOWELE 33 (1998a), 133-53.

Roberts, J. "OE to eME: Looking Forward from the Thesaurus of Old English." In Essays on Anglo-Saxon and Related Themes in Memory of Lynne Grundy, eds. J. Roberts and J. L. Nelson (London: King's College London Medieval Studies, 2000), 435-454.

Roberts, J. “Old English Thesaurus: Report.” Old English Newsletter 21 (2) (1988), 21-23. Roberts, J. "On the Thesaurus of Old English." Medieval English Studies Newsletter 39 (1998b), 8-21. 
Roberts, J. "Some Thoughts on the Representation of Early Middle English in the Historical Thesaurus of English." Dictionaries 23 (2002), 180-207.

Roberts, J. “The English Historical Thesaurus.” Nottingham Linguistic Circular 11 (1982), $20-28$.

Roberts, J. "Towards an Old English Thesaurus." Poetica 9 (1978), 56-72.

Roget $=$ Dutch, R. A., ed. Roget's Thesaurus of English Words and Phrases (London: Longmans, 1962).

Romano, M. “Anger in Old English.” SELIM 9 (1999), 45-56.

Samuels, M. L. "The Role of Functional Selection in the History of English." Transactions of the Philological Society 64 (1) (1965), 15-40.

Samuels, M. L. Linguistic Evolution with Special Reference to English. (Cambridge: Cambridge University Press, 1972).

Sylvester, L., and J. Roberts. "Word Studies on Early English: Contexts for a Thesaurus of Middle English." In A Changing World of Words. Studies in English Historical Lexicography, Lexicology and Semantics, ed. J. E. Díaz Vera (Amsterdam-New York: Rodopi, 2002), 136-159.

$T O E=$ Roberts, J., and C. Kay, with L. Grundy. A Thesaurus of Old English. 2 vols. (London: Centre for Late Antique and Medieval Studies, 1995). A Thesaurus of Old English. Second impression. 2 vols. (Amsterdam \& Atlanta, Ga.: Rodopi, 200o). Edmonds, F., C. Kay, J. Roberts, and I. Wotherspoon, eds. A Thesaurus of Old English Online (2005), http://libra.englang.arts.gla.ac.uk/oethesaurus. Roberts, J., and C. Kay with L. Grundy. A Thesaurus of Old English (Glasgow: University of Glasgow, 2017), http:// oldenglishthesaurus.arts.gla.ac.uk/.

Venezky, R. L., and A. diPaolo Healey. A Microfiche Concordance to Old English. (Toronto: Pontifical Institute of Mediaeval Studies, 1980).

Watanabe, H. "A Thesaurus of Old English Revisited." In Symposium on Lexicography X: Proceedings of the Tenth International Symposium on Lexicography, eds. H. Gottlieb, J. E. Mogensen, and A. Zettersten (Tübingen: Max Niemeyer Verlag, 2002), 313-324. Wotherspoon, I. A. A Notional Classification of Two Parts of English Lexis. Dissertation (University of Glasgow, 1969).

\section{Appendix: Reviews of $A$ Thesaurus of Old English}

Acker, P. Review of TOE, The Medieval Review (2004), no. 04.02.33.

Bremmer Jr, R. H. "Treasure Digging in the Old English Lexicon." Review of TOE, NOWELE 40 (2002), 109-114.

Cavill, P. "Names and Things in Anglo-Saxon and Early Norman England." Review of TOE, Nottingham Medieval Studies 41 (1997), 186-191.

Coleman, J. Review of toE, The Year's Work in English Studies 76 (1) (1998), 11-14. 
Conner, P. W. Review of TOE, Speculum 73 (3) (1998), 887-889.

Dance, R. Review of тоE, Medium Ævum 66 (1997), 312-313.

Gelderen, E. van. Review of TOE, Studies in Language 27 (1) (2003), 200-203.

Görlach, M. Review of TOE, Anglia 116 (3) (1998), 398-401.

Marsden, R. Review of TOE, Leeds Studies in English 31 (2000), 293-295.

Momma, H. Review of TOE, Notes and Queries n.s. 50 (2003), 79-80.

Remley, P. G. Review of TOE, Peritia 14 (2000), 458-461.

Watanabe, H. Review of TOE, Studies in English Literature (1998), 132-138.

Wieland, G. Review of TOE, Mediaevistik 16 (2003), 272-275. 